\title{
Dynamics of bacterioplankton during a phytoplankton bloom in the high Arctic waters of the Franz-Joseph Land archipelago
}

\author{
Gerald Müller-Niklas, Gerhard J. Herndl*
}

Department of Marine Biology, Institute of Zoology, University of Vienna, Althanstr. 14, A-1090 Vienna, Austria

\begin{abstract}
Bacterial abundance and activity were followed during a phytoplankton bloom in the high Arctic, the Franz-Joseph Land archipelago $\left(80^{\circ}\right.$ to $82^{\circ} \mathrm{N}, 45^{\circ}$ to $\left.65^{\circ} \mathrm{E}\right)$, in July 1995 . At the beginning of July the sea was entirely covered by ice; at the end of July the ice coverage was about $50 \%$. Water temperature varied between -1 and $-0.6{ }^{\circ} \mathrm{C}$ and salinity between 32 and $35 \%$. Phytoplankton cells exhibited photoinhibition even during incubation periods when maximum radiation was $<400 \mu \mathrm{E} \mathrm{m}^{-2} \mathrm{~s}^{-1}$. indicating adaption to a low radiation level. Phytoplankton biomass, averaged over all 5 sampling sites, was $2.2 \mu \mathrm{g} \mathrm{chl} \mathrm{a}^{-1}$; primary production, at the $50 \%$ radiation level, was $27.3 \mathrm{\mu g} \mathrm{Cl}^{-1} \mathrm{~d}^{-1}$ and mean bacterial abundance was $3.6 \times 10^{5} \mathrm{ml}^{-1}$. Mean bacterial production as measured by thymidine incorporation was $2.46 \mu \mathrm{g} \mathrm{C} \mathrm{l}^{-1} \mathrm{~d}^{-1}$ while for leucine incorporation it was $5.46 \mu \mathrm{g} \mathrm{C} \mathrm{l}^{-1} \mathrm{~d}^{-1}$ Total organic carbon varied over a narrow range $\left(0.81\right.$ to $\left.1.12 \mathrm{mg} \mathrm{l}^{-1}\right)$. Pronounced spatial variations in microbial parameters between waters surrounding different islands were detectable. At Hayes Island phytoplankton biomass and production decreased within $3 \mathrm{wk}$ while bacterial abundance and activity measured as thymidine and leucine incorporation increased. During this period the percentage of bacterial (as measured by leucine incorporation) to primary production increased from about $3 \%$ to more than $95 \%$ and the calculated total organic carbon turnover decreased from 258 to $28 \mathrm{~d}$.
\end{abstract}

KEY WORDS: Arctic B Bacterioplankton Phytoplankton · Carbon flux

\section{INTRODUCTION}

Over the past $20 \mathrm{yr}$, the concept of the structure of aquatic food webs has changed (Pomeroy 1974, Azam et al. 1983) with bacterioplankton playing a central role in the cycling of organic matter, converting up to $80 \%$ of the pelagic primary production (Fuhrman et al. 1989, Cho \& Azam 1990, Ducklow \& Carlson 1992). In the Arctic Ocean, however, the microbial food webs are probably not as effective and tightly coupled as in temperate waters (Pomeroy \& Deibel 1986).

In high Arctic regions, physical parameters determine, to a large extent, the interactions between bacteria and phytoplankton. On a seasonal basis, irradiance controls phytoplankton productivity in the Arctic Ocean (Smith \& Sakshaug 1990) while it has been proposed that bacterial growth is suppressed by low

- Addressee for correspondence.

E-mail: gerhard.herndl@univie.ac.at temperature and substrate concentrations (Pomeroy \& Deibel 1986, Pomeroy et al. 1991, Wiebe et al. 1992). Microbial processing of organic matter is the most important pathway of nutrient remineralization in temperate waters (Pomeroy 1974, Azam et al. 1983). Hence microbes determine the amount of organic material available for the planktonic metazoan communities and the rate of vertical carbon flux. If water temperature is below $1^{\circ} \mathrm{C}$ during periods of high primary productivity, bacterial production could remain low despite high nutrient concentrations (Pomeroy \& Deibel 1986), resulting in an accumulation of organic matter in the water column. This scenario is supported by findings of Peterson \& Curtis (1980) and Atkinson \& Wacasey (1987) who showed that a larger portion of water column production sediments to the bottom in polar than in tropical or temperate regions. High sedimentation rates, however, could also be caused by an uncoupling of primary production from herbivorous feeding by mesozooplankton 
Productivity in the water column under the permanent ice of the central Arctic Ocean is considered to be low due to the limited availability of light and low temperature (Apollonio 1959, Pomeroy et al. 1990). Above the Arctic shelf, which is mostly under seasonal ice cover, annual primary production usually varies between 50 and $100 \mathrm{~g} \mathrm{C} \mathrm{m}^{-2} \mathrm{yr}^{-1}$ (Grebmeier et al. 1995). The present study focuses on the shelf area of the Barents Sea which is one of the largest shelf areas of the Arctic Ocean covering 1.4 million $\mathrm{km}^{2}$ or about $10 \%$ of the entire Arctic Ocean (Loeng 1991). While numerous reports have been published on the carbon flow through the pelagic ecosystem of the central and western Barents Sea (Wassmann \& Slagstad 1993, Kristiansen et al. 1994, Sakshaug et al. 1994) little is known about its castcrn parts.

In this study we investigated the productivity of the nearshore waters of the Franz-Joseph Land archipelago. During the summer phytoplankton bloom, we measured phytoplankton biomass and production, bacterial abundance and activity as well as the con- centration of total organic carbon at 5 different sampling sites. Since the archipelago covers an area of $2^{\circ}$ of latitude and breakage of pack ice starts mainly in the southwestern part of the archipelago, which is influenced by the warmer waters of the Barents Sea current of the Atlantic Layer (Anderson 1995), we focused on the spatial and temporal variability in bacterioplankton productivity from the far north to the southernmost islands from wax to wane of the phytoplankton bloom.

\section{MATERIAL AND METHODS}

Study site and sampling. The study was carried out in the Franz-Joscph Land archipclago $180^{\circ}$ to $82^{\circ} \mathrm{N}$ $45^{\circ}$ to $65^{\circ} \mathrm{E}$ ) in July 1995 (Fig. 1). Samples were taken at 5 different locations ranging from one of the southernmost to the northernmost island (Fig. 1) to investigate potential spatial variability in phyto- and bacterioplankton activity. At Ziegler Island we performed 3

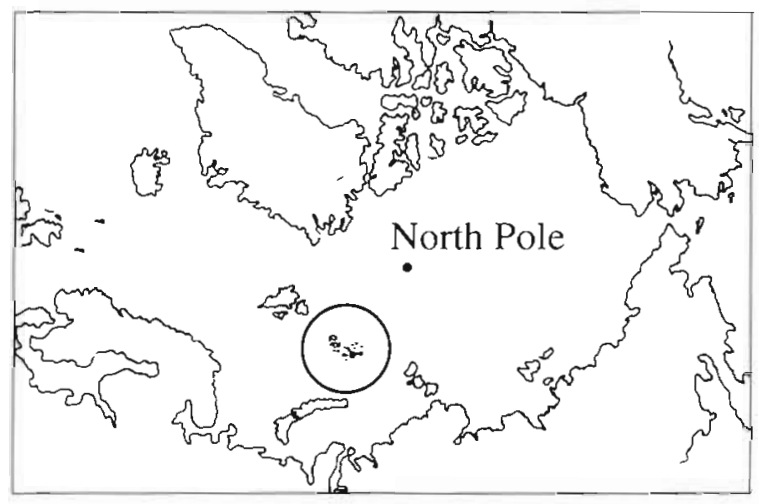

\section{$81^{\circ}$}

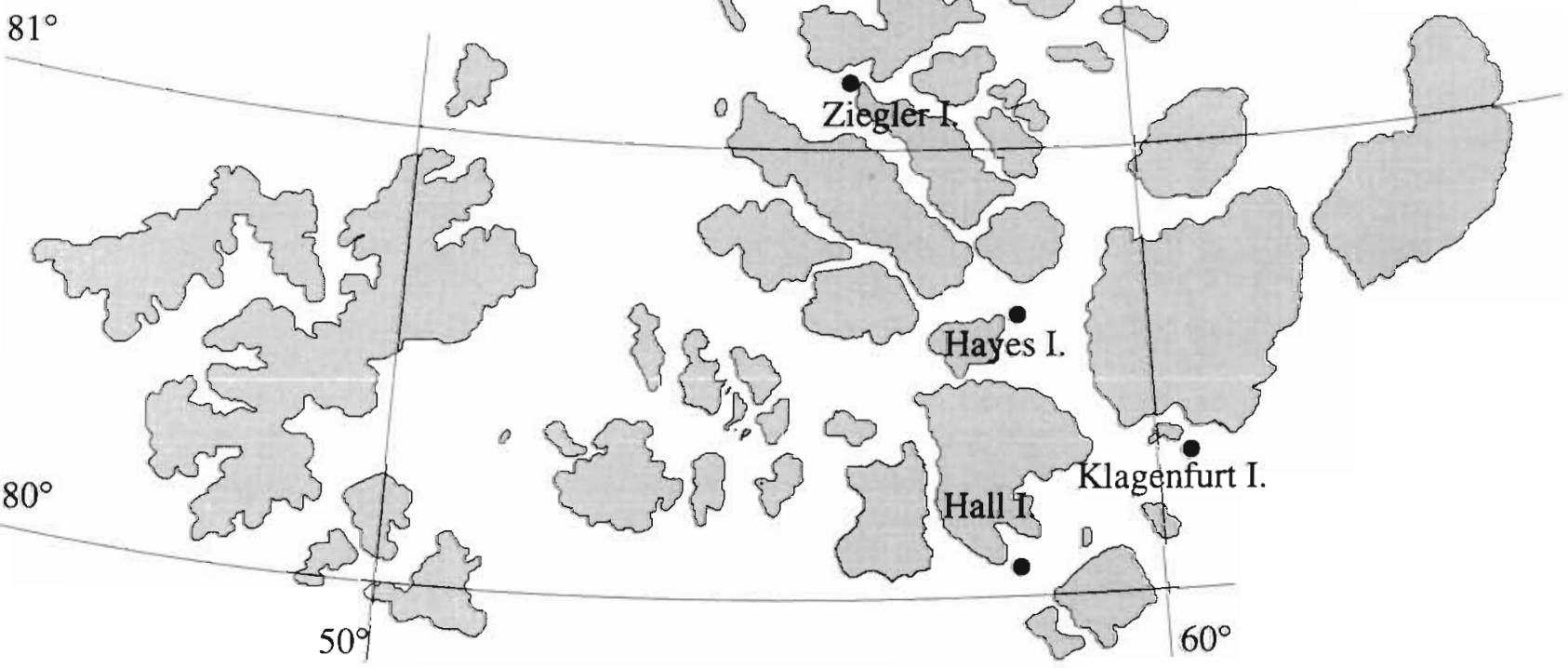

Fig. 1. Franz-Joseph Land archipelago and the sampling sites 
samplings, at Hayes Island 5 samplings and at the other islands 1 sampling was carried out. At Hayes Island (Fig 1) the samples were taken over an investigation period of $3 \mathrm{wk}$ in order to follow the development of a phytoplankton bloom. At the beginning of July, the sea was almost entirely ice-covered; at the end of the month ice coverage was about $50 \%$. The water depth at the sampling locations was $>20 \mathrm{~m}$. Water samples were taken with clean Niskin bottles from $5 \mathrm{~m}$ depth through openings in the ice. The samples were kept at in situ temperature during transport by helicopter and brought to the laboratory within $2 \mathrm{~h}$ for future processing.

Temperature and irradiation. Temperature of the water was determined immediately after sampling and prior to the incubations for primary and bacterial production as well as of the snow where the incubations were performed in order to provide in situ temperature conditions during the entire incubation period. Light intensity was measured with a cosine sensor and a LICOR (LI-1000) radiometer.

Phytoplankton biomass and primary production. To estimate phytoplankton biomass, $3 \mathrm{l}$ of seawater was filtered onto glass fiber filters (Whatman GF/F, $47 \mathrm{~mm}$ diameter) and kept frozen $\left(-20^{\circ} \mathrm{C}\right)$ until analysis. For chlorophyll a (chl a) determination, filters were extracted in $10 \mathrm{ml}$ of $90 \%(\mathrm{v} / \mathrm{v})$ acetone and stored refrigerated overnight. Before spectrophotometrically measuring chl $a$, acetone extractions were filtered again through Whatman GF/F filters to remove particles. For calculating chl a concentrations, the method and formulas given in Parsons et al. (1984) were used. Determination of phaeopigments was done by acidifying the acetone extractions with a few drops of $10 \%(\mathrm{v} / \mathrm{v})$ hydrochloric acid and calculating phaeopigment concentration as outlined in Parsons et al. (1984).

Primary production was estimated using the ${ }^{14} \mathrm{C}$ radiolabeling technique (Parsons et al. 1984). The amount of photosynthetic extracellular release (PER) was estimated using the method described by Lignell $(1990,1992)$. Winkler flasks $(120 \mathrm{ml})$ were filled with $100 \mathrm{ml}$ of seawater; to each flask $1 \mathrm{ml}$ of $2 \mu \mathrm{Ci} \mathrm{ml}^{-1}$ of sodium ${ }^{14} \mathrm{C}$-bicarbonate (specific activity, S.A., $0.8 \mathrm{mCi}$ $\mathrm{mmol}^{-1}$; American Radiolabeled Chemicals, Inc.) was added and incubated in duplicates at 3 different irradiance levels $(100,50$ and $0 \%$ of suface irradiance) for $24 \mathrm{~h}$ from dawn to dawn. The flasks were placed in the snow to keep the temperature close to in situ conditions $\left(-0.5\right.$ and $-0.8^{\circ} \mathrm{C}$ ) (see Table 1$)$. The radiation to which the flasks were exposed was monitored at $4 \mathrm{~h}$ intervals. The incubations were ended by placing the flasks in a dark box. The time between terminating the incubation and starting the filtration procedure was generally less than 5 min. Samples were filtered through cellulose nitrate filters (Millipore $25 \mathrm{~mm}$ diam- eter, $0.45 \mu \mathrm{m}$ pore size) by applying a suction pressure not exceeding $20 \mathrm{mbar}$. Filters were rinsed twice with $0.2 \mu \mathrm{m}$ filtered seawater (Millipore polycarbonate filter, $47 \mathrm{~mm}$ diameter, $0.2 \mu \mathrm{m}$ pore size) from the same sample location. Thereafter, the filters were fumed over concentrated $\mathrm{HCl}$ for 10 min to remove inorganic carbon, placed in scintillation vials and stored frozen until analysis at the Inst. of Zoology (Univ. of Vienna, Austria). The filters were then dissolved in $1 \mathrm{ml}$ ethylacetate; after $10 \mathrm{~min}, 8 \mathrm{ml}$ scintillation cocktail (Packard Insta-Gel) was added. Radioactivity was measured about $12 \mathrm{~h}$ after adding the scintillation cocktail Before rinsing the filters, $3 \mathrm{ml}$ of the filtrate was transferred to scintillation vials, acidified with $20 \mu$ l concentrated $\mathrm{H}_{2} \mathrm{SO}_{4}$, left open for $24 \mathrm{~h}$ and subsequently stored frozen until analysis. Before analysis $7 \mathrm{ml}$ of scintillation cocktail was added to the filtrates and the radioactivity assayed after 14 to $16 \mathrm{~h}$ in a liquid scintillation counter (Packard TriCarb 2000). Quenching was corrected by the external standard technique. For calculating primary productivity, dark values were subtracted from corresponding light values.

Bacterial abundance and production. Bacterial abundance was determined by acridine orange staining and epifluorescence microscopy on black polycarbonate membrane filters (Millipore, diameter $25 \mathrm{~mm}$, $0.2 \mu \mathrm{m}$ pore size) (Hobbie et al. 1977). Samples (5 ml) were fixed with $0.2 \mathrm{ml}$ of $0.2 \mu \mathrm{m}$ filtered, concentrated formalin and then stained with a few drops of an acridine orange solution ( $0.2 \mu \mathrm{m}$ filtered) for $5 \mathrm{~min}$. After filtration, the filters were embedded in paraffin oil and stored frozen until counting with a Leitz Laborlux microscope equipped with a Ploemopak epifluorescence unit. To convert bacterial abundance into carbon equivalents we assumed a carbon content of $20 \mathrm{fg} \mathrm{C}$ cell $^{-1}$ (Lee \& Fuhrman 1987).

Bacterial production was estimated by simultaneously measuring the incorporation of $\left[{ }^{3} \mathrm{H}\right]$-thymidine (S.A. $86 \mathrm{Ci} \mathrm{mmol}^{-1}$; American Radiolabeled Chemicals, Inc., final conc. $5 \mathrm{nM}$ ) and $\left[{ }^{14} \mathrm{C}\right.$-leucine (S.A. $292 \mathrm{mCi}$ $\mathrm{mmol}^{-1}$; American Radiolabeled Chemicals, Inc., final conc. $20 \mathrm{nM}$ ) (Chin-Leo \& Kirchman 1988). Samples $(25 \mathrm{ml})$ were incubated in 6 replicates and 4 blanks in gamma-radiated test tubes (Greiner, Inc.); blanks were fixed with concentrated formalin at a final concentration of $4 \%(\mathrm{v} / \mathrm{v})$. The samples were wrapped in aluminum foil and incubated in snow (temperature range: -0.5 and $-0.8^{\circ} \mathrm{C}$, reflecting in situ temperature of the seawater) for $4 \mathrm{~h}$. After incubation, the samples were filtered onto cellulose nitrate filters (Millipore $25 \mathrm{~mm}$ diameter, $0.45 \mu \mathrm{m}$ pore size) and extracted twice with $20 \mathrm{ml}$ ice-cold $5 \%$ trichloracetic acid (Sigma Chemicals) for $5 \mathrm{~min}$. The filters were transferred into scintillation vials and stored frozen until analysis. The filters were then dissolved in $1 \mathrm{ml}$ ethylacetate; after $10 \mathrm{~min}$, 
$8 \mathrm{ml}$ scintillation cocktail (Packard Insta-Gel) was added. Radioactivity was measured as described above. Conversion factors of $1.1 \times 10^{18} \mathrm{cells}^{\mathrm{mol}} \mathrm{l}^{-1}$ thymidine incorporated into bacteria (Bjørnsen \& Kuparinen 1991 ) and $3.0 \mathrm{~kg} \mathrm{C} \mathrm{mol}{ }^{-1}$ leucine incorporated into bacteria (Bjørnsen \& Kuparinen 1991) were used.

Total organic carbon. Unfiltered samples for analysis of total organic carbon (TOC) were stored in combusted ampoules at $-20^{\circ} \mathrm{C}$ until analysis. TOC content was determined using a Shimadzu TOC 5000 after sparging the sample with $\mathrm{CO}_{2}$-free air. Standards were prepared with potassium hydrogen phthalate (Kanto Chemical Co, Inc.); a platinum catalyst on quartz was used (Benner \& Strom 1993).

Unless otherwise stated all the parameters were measured in duplicate.

\section{RESULTS}

Temperature and radiation. During the investigation period water temperature at $5 \mathrm{~m}$ depth varied between -1 and $-0.6^{\circ} \mathrm{C}$ (Table 1 ). Surface radiation at noon ranged from 370 to $1600 \mu \mathrm{E} \mathrm{m}^{-2} \mathrm{~s}^{-1}$ and at midnight from 10 to $140 \mu \mathrm{E} \mathrm{m} \mathrm{m}^{-2} \mathrm{~s}^{-1}$

Spatial variability in phyto- and bacterioplankton. Mean phytoplankton biomass, averaged over all sampling sites and dates, was $2.2 \mu \mathrm{g} \mathrm{chl} \mathrm{a} \mathrm{l}^{-1}$ (range 0.37 to

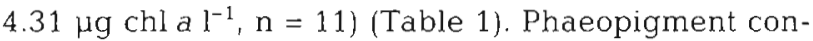
centration was always below the detection limit. Primary production in samples exposed to $50 \%$ of surface radiation was always higher (mean $=2.5 x_{i}$ range 1.01 to $6.02 \times, n=11$ ) than that at surface radiation levels (Table 1 ). Mean primary production at the $50 \%$ radia-

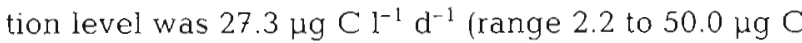
$1^{-1} d^{-1}, n=11$; Table 1$)$. The photosynthetic extracellular release was always below $3 \%$ of total primary production (particulate + extracellular release). Mean specific productivity at the $50 \%$ radiation level was $0.56 \mathrm{~g} \mathrm{C} \mathrm{g}^{-1} \mathrm{chl} \mathrm{a} \mathrm{h}^{-1}$ (range 0.16 to $1.59 \mathrm{~g} \mathrm{C} \mathrm{g}^{-1} \mathrm{chl}$ a $\mathrm{h}^{-1}, \mathrm{n}=11$; Table 1 ). Mean bacterial abundance of all sampling sites and dates was $3.6 \times 10^{5}$ cells $\mathrm{ml}^{-1}$ (range 2.1 to $5.8 \times 10^{5}$ cells $\mathrm{ml}^{-1}, \mathrm{n}=11$; Table 1 ). Bacterial production as measured by thymidine incorporation (mean $=2.46 \mu \mathrm{g} \mathrm{C} \mathrm{l}^{-1} \mathrm{~d}^{-1}$, range 0.9 to $4.6 \mu \mathrm{gC} \mathrm{l}^{-1} \mathrm{~d}^{-1}$, $n=11)$ was always lower than that measured by leu-

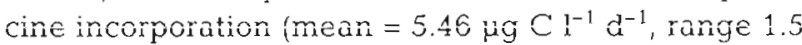
to $12.8 \mu \mathrm{g} \mathrm{C} \mathrm{l}^{-1} \mathrm{~d}^{-1}, \mathrm{n}=11$; Table 1 ).

If the parameters measured at different sampling sites are compared, pronounced variations for phytoplankton and bacterial leucine incorporation become evident (Fig. 2). Phytoplankton biomass and primary production varied greatly, ranging from 0.46 to $3.2 \mu \mathrm{g}$

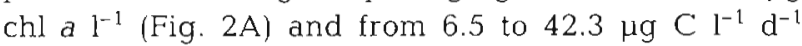
(Fig. 2B), respectively. On the other hand, bacterial abundance and production as measured by thymidine incorporation remained rather stable, ranging from 2.4 to $3.13 \times 10^{5}$ cells ml $^{-1}$ (Fig. $2 \mathrm{C}$ ) and from 2.2 to $3.1 \mu \mathrm{g}$ $\mathrm{C}^{-1} \mathrm{~d}^{-1}$ (Fig. 2D), respectively. Bacterial production measured by leucine incorporation showed greater variability (3.1 to $\left.7.4 \mu \mathrm{g} \mathrm{C} \mathrm{l}^{-1} \mathrm{~d}^{-1}\right)$ than that measured by thymidine incorporation (Fig 2D). The ratio of

Table 1. Physical, chemical and microbial parameters at the 5 sampling sites in the Franz-Joseph Land archipelago. Temp: temperature; TOC: total organic carbon; Bact. abund.: bacterial abundance; Bact. production: bacterial production; TdR: thymidine incorporation; Leu: leucine incorporation; Bact. DT bacterial doubling time (as estimated from thymidine incorporation); Chl a: chlorophyll $a_{i}$ Specific prod.. specific productivity (calculated from primary production at the $50 \%$ radiation level)

\begin{tabular}{|c|c|c|c|c|c|c|c|c|c|c|c|}
\hline \multirow[t]{2}{*}{ lsland } & \multirow{2}{*}{$\begin{array}{l}\text { Date } \\
\text { (day of } \\
\text { July } \\
\text { 1995) }\end{array}$} & \multirow[t]{2}{*}{$\begin{array}{l}\text { Temp } \\
\left({ }^{\circ} \mathrm{C}\right)\end{array}$} & \multirow[t]{2}{*}{$\begin{array}{c}\text { TOC } \\
\left(m g 1^{-1}\right)\end{array}$} & \multirow[t]{2}{*}{$\begin{array}{c}\text { Bact. } \\
\text { abund. } \\
\left(\times 10^{5} \mathrm{ml}^{-1}\right)\end{array}$} & \multicolumn{2}{|c|}{$\begin{array}{c}\text { Bact. } \\
\text { production } \\
\left(\mu \mathrm{g} \mathrm{Cl^{-1 }} \mathrm{d}^{-1}\right)\end{array}$} & \multirow[t]{2}{*}{$\begin{array}{l}\text { Bact. DT } \\
\text { (days) }\end{array}$} & \multirow[t]{2}{*}{$\begin{array}{l}\text { Chl a } \\
\left(\mu g^{-1}\right)\end{array}$} & \multirow{2}{*}{\multicolumn{2}{|c|}{$\begin{array}{c}\text { Primary } \\
\text { production } \\
\left(\mu \mathrm{g} \mathrm{C} \mathrm{l}^{-1} \mathrm{~d}^{-1}\right) \\
\% \text { of surface } \\
\text { radiation: } \\
50 \quad 100\end{array}$}} & \multirow[t]{2}{*}{$\begin{array}{c}\text { Specific } \\
\text { prod. } \\
\left(\mathrm{g} \subset \mathrm{g}^{-1} \mathrm{chl} a \mathrm{~h}^{-1}\right)\end{array}$} \\
\hline & & & & & $\mathrm{TdR}$ & Leu & & & & & \\
\hline Ziegler & 07 & -1.0 & 1.07 & 3.6 & 3.8 & 2.1 & 1.9 & 0.37 & 13.9 & 3.4 & 1.59 \\
\hline Hayes & 08 & -0.6 & 0.94 & 2.1 & 0.9 & 1.5 & 4.5 & 3.63 & 50.0 & 26.7 & 0.57 \\
\hline Hall & 11 & -0.7 & 0.87 & 5.1 & 3.1 & 4.7 & 3.3 & 1.67 & 22.9 & 3.8 & 0.57 \\
\hline Klagenfurt & 13 & -0.6 & 0.94 & 4.7 & 2.6 & 3.1 & 3.6 & 2.85 & 42.3 & 30.9 & 0.62 \\
\hline Hayes & 14 & -0.7 & 1.12 & 3.2 & 1.7 & 5.3 & 3.7 & 3.93 & 39.0 & 18.7 & 0.41 \\
\hline Hayes & 15 & -0.6 & 0.89 & 2.3 & 1.7 & 4.6 & 2.7 & 4.31 & 46.6 & 24.6 & 0.45 \\
\hline Rudolph & 16 & -0.8 & 0.91 & 2.4 & 2.3 & 6.1 & 2.2 & 2.37 & 38.7 & 19.9 & 0.68 \\
\hline Ziegler & 19 & -0.7 & 0.81 & 3.0 & 1.7 & 3.5 & 3.6 & 0.57 & 2.2 & 2.1 & 0.16 \\
\hline Ziegler & 22 & -0.7 & 0.83 & 2.8 & 1.2 & 5.0 & 4.6 & 0.43 & 3.5 & 1.6 & 0.34 \\
\hline Hayes & 24 & -0.6 & 0.91 & 58 & 4.6 & 12.8 & 2.5 & 1.63 & 13.2 & 3.7 & 0.34 \\
\hline Hayes & 25 & -0.7 & 0.88 & 5.4 & 3.6 & 11.6 & 3.0 & 2.48 & 28.1 & 18.5 & 0.47 \\
\hline Mean & & -0.7 & 0.92 & 3.6 & 2.5 & 5.5 & 3.2 & 2.20 & 27.3 & 13.9 & 0.56 \\
\hline SD & & & 0.09 & 1.3 & 1.1 & 3.6 & 0.8 & 1.34 & 17.6 & 11.2 & 0.16 \\
\hline
\end{tabular}



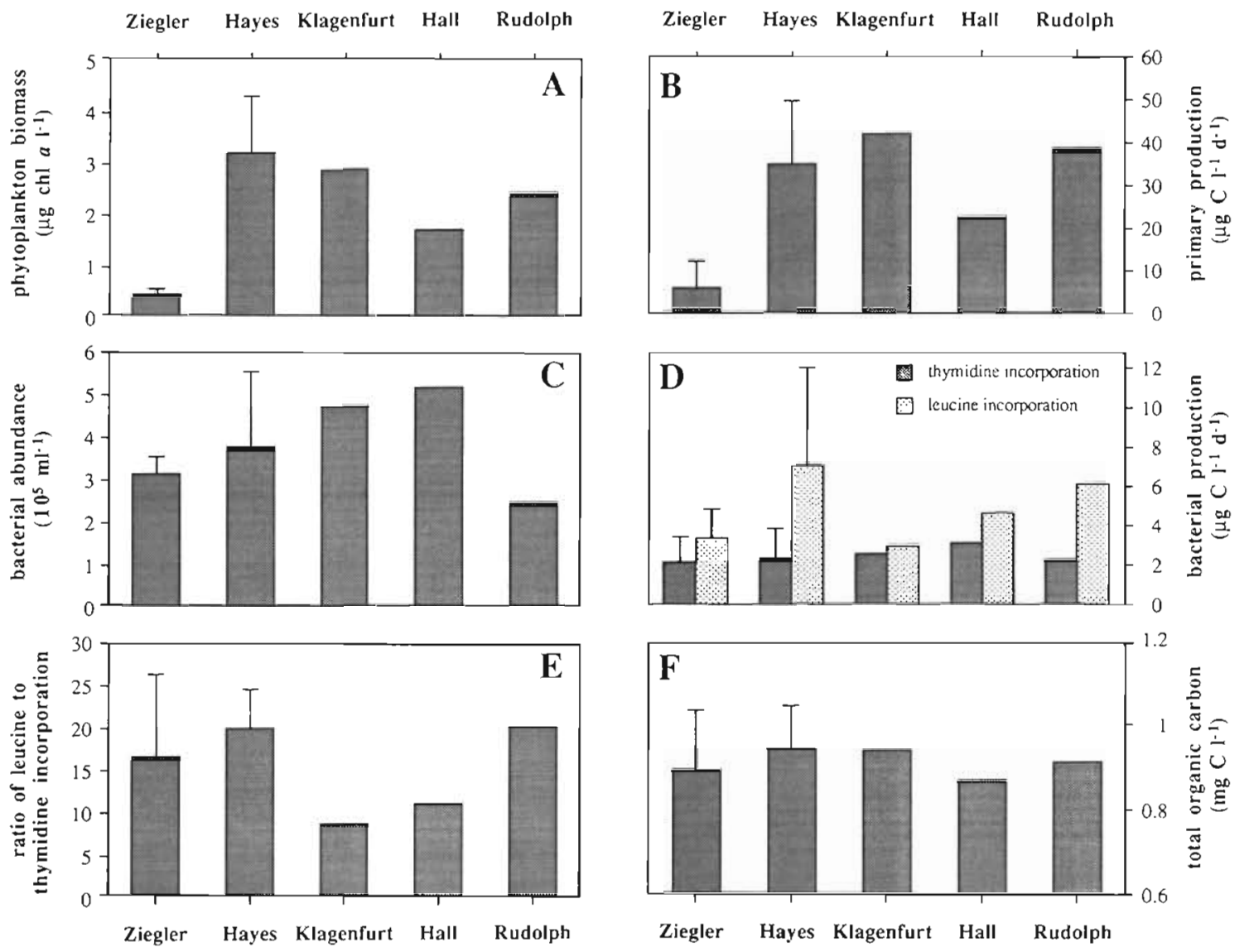

Fig. 2. Spatial variability of (A) phytoplankton biomass, (B) primary production, bacterial (C) abundance, and (D) production, (E) ratio of leucine to thymidine incorporation, and $(F)$ the concentration of total organic carbon at the 5 sampling sites in the Franz-Joseph Land archipelago at Ziegler. Hayes, Klagenfurt, Hall and Rudolph islands. Vertıcal lines: standard error of replicate measurements

thymidine incorporation to leucine incorporation varied between 8.6 and 19.9 (Fig. 2E).

Total organic carbon. The concentration of TOC did not exhibit pronounced variations, ranging from 0.81 to $1.12 \mathrm{mg} \mathrm{l}^{-1}$ (mean $=0.92, \mathrm{n}=11$ ) (Fig. 2F).

Temporal variability in phyto- and bacterioplankton. At Hayes Island, sampling was performed 5 times over $3 \mathrm{wk}$ allowing us to detect a distinct temporal pattern in both phyto- and bacterioplankton. Phytoplankton biomass decreased significantly from 8 to 25 July while, concurrently, bacterial abundance increased (Fig. 3A). Similar to phytoplankton biomass, primary production also decreased while both thymidine and leucine incorporation increased (Fig. 3B). During the entire investigation period the concentration of TOC remained fairly constant (Fig. 3C).

\section{DISCUSSION}

The Franz-Joseph Land archipelago is situated at the edge of the permanent pack ice and is covered by sea- sonal ice until early July. Summer peaks in primary production usually follow the retreating ice zone from the south to the north of the Barents Sea (Anderson 1995). Sampling during this period allowed us to follow the development of the phytoplankton bloom. In order to avoid inclusion of ice algae and melting water during sampling we regularly checked temperature (always $<0^{\circ} \mathrm{C}$ ) in our water samples. This indicated that inclusion of melting water was negligible since melting water usually exhibits a temperature $>0^{\circ} \mathrm{C}$ (Kristiansen \& Lund 1989). In July, the photoperiod is $24 \mathrm{~h}$, with light intensities at noon between 370 and $1600 \mu \mathrm{E} \mathrm{m}^{-2} \mathrm{~s}^{-1}$ and at midnight between 10 and $140 \mu \mathrm{E} \mathrm{m}^{-2} \mathrm{~s}^{-1}$. Phytoplankton appeared to be well adapted to low irradiance levels. Primary production in samples exposed to $50 \%$ of surface radiation was, on average, 2.5 times higher than at surface radiation levels. This indicates photoinhibition even during days with maximum irradiance of $<400 \mu \mathrm{E} \mathrm{m}^{-2} \mathrm{~s}^{-1}$, corresponding with data summarized in Kirst \& Wiencke (1995); while photoinhibition might occur at radiation levels $<400 \mu \mathrm{E} \mathrm{m}^{-2} \mathrm{~s}^{-1}$. Arctic phytoplankton can also 

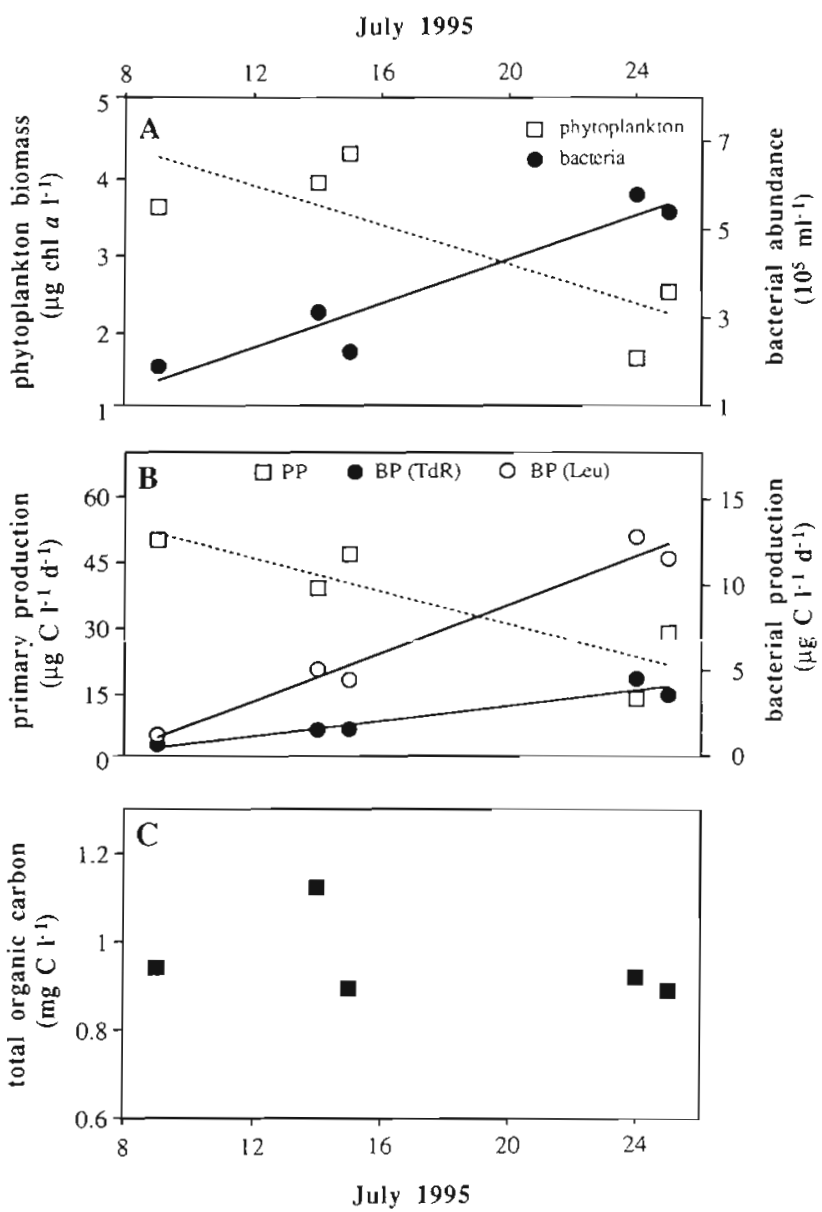

Fig. 3. Phytoplankton and bacterial dynamics and concentration of total organic carbon (TOC) at Hayes Island during July 1995. (A) Phytoplankton biomass decreased significantly $(y=$ $\left.-0.1 x+5.5, n=5, x^{2}=0.648, p<0.05\right)$ during the investigation period while concurrently bacterial abundance increased significantly $\left(y=0.2 x-0.5, \mathrm{n}=5, \mathrm{r}^{2}=0.907, \mathrm{p}<0.001\right)$. (B) Primary production (PP) decreased significantly $(y=-1.9 x+68.9$, $\mathrm{n}=5, \mathrm{r}^{2}=0.78, \mathrm{p}<0.01$ ) during the investigation period while bacterial production (BP) as measured by thymidine incorporation $\left(y=0.2 x-1.2, \mathrm{n}=5, \mathrm{r}^{2}=0.909, \mathrm{p}<0.001\right)$ and leucine incorporation $\left(y=0.7 x-4.9, \mathrm{n}=5, \mathrm{r}^{2}=0.969, \mathrm{p}<0.001\right)$ increased significantly. (C) Concentration of TOC did not exhibit significant changes

be adapted to irradiation levels up to $2000 \mu \mathrm{E} \mathrm{m} \mathrm{m}^{-2} \mathrm{~s}^{-1}$ (Kirst \& Wiencke 1995). Adaptation to low radiation levels might be caused by the high percentage of ice cover during summer. Moreover, Kirst \& Wiencke (1995) showed that phytoplankton cells adapted to low radiation intensities are unable to adapt to radiation levels $>400 \mu \mathrm{E} \mathrm{m}^{-2} \mathrm{~s}^{-1}$ if exposed to these high radiation levels for only a short period of time.

Samples were taken on 5 different islands to examine the spatial variability within the archipelago. Temporal trends as obtained at Hayes Island (Fig. 3) were not detectable if all the data from all islands were pooled. For example at Ziegler Island, phytoplankton biomass and primary production were always lowest (Fig. 2A, B), although the first sampling was performed in early July when phytoplankton biomass and production were already high at Hayes Island (Fig. 2A, B). Moreover, there is no latitudinal trend detectable from one of the southernmost islands (Hall Island) to the northernmost Rudolph Island (Fig. 1). The relation between bacterial and phytoplankton parameters varied depending on the sampling sites (Fig. 2A-D). Furthermore, we could not find a significant correlation between bacterial abundance and chl a and between bacterial and primary production as has been reported for a variety of pelagic systems (Cole et al. 1988), indicating an uncoupling of bacteria and phytoplankton (Duckluw \& Kirchindn 1983, Kirchman el di. 1989, Cho et al. 1994). The ratio of leucine to thymidine incorporation varies among different islands (Fig. 2E) which might be attributed to unbalanced growth caused by a rapidly fluctuating environment (Chin-Leo \& Kirchman 1990) or simply by changes in the ratio between uptake of TdR or leucine and the cell or biomass production, respectively.

At Hayes Island (Fig. 1) we started sampling in early July; phytoplankton biomass and production were highest during this period (Fig. $3 \mathrm{~A}, \mathrm{~B}$ ), although the sea was almost entirely covered by ice. During the following $3 \mathrm{wk}$, phytoplankton biomass and production decreased to approximately half of the initial values (Fig. 3A, B). Therefore, we have evidence that highest phytoplankton biomass and productivity in this area occur before the pack ice breaks up but most probably after the melting of snow when irradiance is high enough to penetrate through the ice. This is supported by findings of Bergmann et al. (1991) showing that snow cover can account for 70 to $80 \%$ of the variance in sub-ice chlorophyll concentrations. A common feature of the Barents Sea is that phytoplankton blooms can rapidly develop and decay, sometimes within 1 to 2 wk (Sakshaug \& Slagstad 1991). The decay of Arctic phytoplankton blooms is mostly attributed to nutrient depletion in the surface layer (Harrison \& Cota 1991, Anderson 1995). There is evidence that nutrient deficiency results in substantial photosynthetic extracellular release (PER) (Larsson \& Hagström 1982, Lancelot 1983, Obernosterer \& Herndl 1995) and decaying phytoplankton cells should exhibit a decreasing chl a: phaeopigment ratio. However, we could never detect significant amounts of PER or phaeopigment concentration and chl a specific production remained stable during the investigation period off Hayes Island. This indicates, along with the findings of Kristiansen et al. (1994), that the phytoplankton community in the Barents Sea is nitrogen-replete throughout the season, suggesting mechanisms other than nitrogen depletion 
to be reponsible for the observed decrease in phytoplankton biomass.

While phytoplankton biomass and production decreased, bacterial abundance and bacterial production as measured by thymidine and leucine incorporation increased significantly during the investigation period (Fig. 3A, B). Findings on the importance of bacterial activity in cold waters are to some extent conflicting. It has been suggested that photosynthesis is less supressed by low temperature than bacterial metabolism and that microbial food webs in cold waters are therefore not as effective as in temperate waters (Pomeroy \& Deibel 1986, Pomeroy et al. 1990, 1991). Other authors found bacteria to be quantitatively important in Antarctic waters (Hodson et al. 1981, Hanson et al. 1983). Although primary production was measured only at 2 radiation levels, and therefore extrapolations on an ecosystem level cannot be made, we can compare the relation between bacterial and primary production. In early July bacterial production was low compared to primary production, comprising only 2.9 and $1.8 \%$ of primary production, calculated from leucine and thymidine incorporations, respectively (Fig. 4). Three weeks later the percentage of bacterial to primary production was 97 and $34 \%$, respectively (Fig. 4). Pomeroy et al. (1991) reported a percentage of bacterial carbon demand to primary production of about 0.8 and $8 \%$ during the early and senescent phases of a phytoplankton bloom, respectively, in the cold waters off Newfoundland. Both high and low percentages of bacterial to primary production in cold waters have been reported ranging from 1 to $3000 \%$ as summarized in Ducklow \& Carlson (1992). Moreover, bacterial carbon demand (estimated from leucine incorporation and assuming a growth yield of

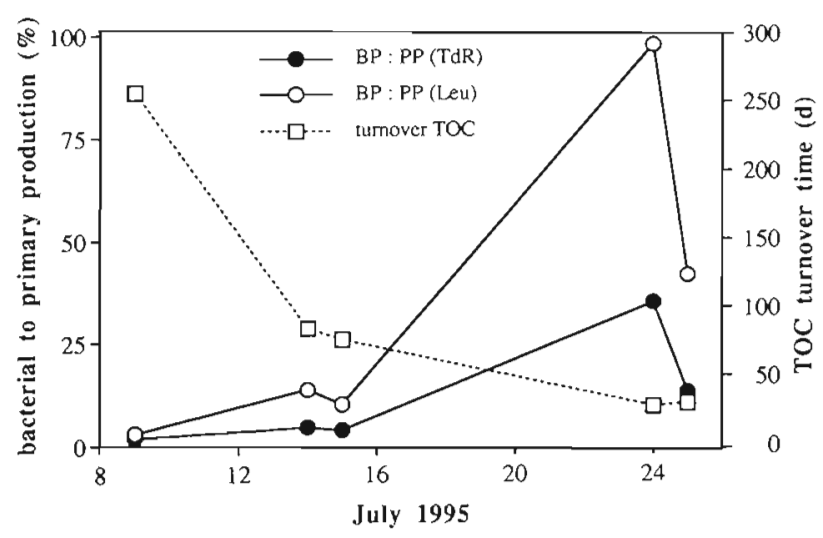

Fig. 4. Temporal changes in the percentage of bacterial production (BP) measured by thymidine (TdR) and leucine (Leu) incorporation in relation to primary production (PP) (left $y$ axis) and the fluctuation in total organic carbon (TOC) turnover time (right $y$-axis) during the investigation period off Hayes Island
40\%; Bjørnsen \& Kuparinen 1991) revealed a TOC turnover time of $258 \mathrm{~d}$ in early July; within $3 \mathrm{wk}$ the TOC turnover time decreased to $28 \mathrm{~d}$ (Fig. 4). The latter is similar to turnover times of dissolved organic carbon of about 3 to $40 \mathrm{~d}$ reported for a phytoplankton bloom in North Atlantic waters (Kirchman et al. 1991). Therefore, the nearshore systems of this archipelago are net autotrophic during phases of high primary production when bacterial carbon uptake is still low, but changes rapidly to a net heterotrophic system during the summer season.

In conclusion, we have shown that during summer in the Franz-Joseph Land archipelago the ratio between autotrophs and heterotrophic bacteria changes within weeks from periods with high phytoplankton biomass and production and insignificant bacterial carbon uptake to a system dominated by bacterioplankton activity. Thus, phases of production and degradation of organic matter are separated in time. Moreover, there is a pronounced spatial variability in phytoplankton and bacterial leucine incorporation within the archipelago.

Acknowledgements. Special thanks go to Wolfram Richter for organizing this expedition and to Alexander Riegler and Michaela Panzenböck for invaluable help. This study was supported by the Austrian Science Foundation (FWF P11132$\mathrm{BIO}$ ). The work is part of the fulfillment of the requirements towards a Ph.D. degree at the University of Vienna by G.M.-N.

\section{LITERATURE CITED}

Anderson LG (1995) Chemical oceanography of the Arctic and its shelf seas. In: Smith WO Jr, Grebmeier JM (eds) Arctic oceanography: marginal ice zones and continental shelves. American Geophysical Union, Washington, DC, p 183-202

Apollonio $S$ (1959) Hydrobiological measurements on IGY Drifting Station Bravo. Trans Am Geophys Un 40:316-319

Atkinson EG, Wacasey JW (1987) Sedimentation in Arctic Canada: particulate organic carbon flux to a shallow marine benthic community in Frobisher Bay. Polar Biol 8: $3-7$

Azam F, Fenchel T, Field JG, Gray JS, Meyer-Reil LA, Thingstad $F$ (1983) The ecological role of water-column microbes in the sea. Mar Ecol Prog Ser 10:257-263

Benner R, Strom M (1993) A critical evaluation of the analytical blank associated with DOC measurements by hightemperature catalytic oxidation. Mar Chem 41:153-160

Bergmann MA, Welch HE, Walker-Butler J, Siferd TD (1991) Ice algal photosynthesis at Resolute and Saqvaqjuac in the Canadian Arctic. J Mar Syst 2:43-52

Bjørnsen PK, Kuparinen J (1991) Determination of bacterioplankton biomass, net production and growth efficiency in the Southern Ocean. Mar Ecol Prog Ser 71:185-194

Chin-Leo G, Kirchman DL (1988) Estimating bacterial production in marine waters from the simultaneous incorporation of thymidine and leucine. Appl Environ Microbiol $54: 1934-1939$

Chin-Leo G, Kirchman DL (1990) Unbalanced growth in natural assemblages of marine bacterioplankton. Mar Ecol Prog Ser 63:1-8 
Cho BC, Azam F (1990) Biogeochemical significance of bacterial biomass in the ocean's euphotic zone. Mar Ecol Prog Ser 63:253-259

Cho BC, Choi JK, Chung CS, Hong CH (1994) Uncoupling of bacteria and phytoplankton during a spring diatom bloom in the mouth of the Yellow Sea. Mar Ecol Prog Ser 115: $181-190$

Cole JJ, Findlay S, Pace ML (1988) Bacterial production in fresh and saltwater ecosystems: a cross-system overview. Mar Ecol Prog Ser 43:1-10

Ducklow HW, Carlson CA (1992) Oceanic bacterial production. In: Marshall KC (ed) Advances in microbial ecology. Plenum Press, New York, p 113-181

Ducklow HW, Kirchman DL (1983) Bacterial dynamics and distribution during a spring bloom in the Hudson River bloom, USA. J Plankton Res 5:333-355

Fuhrman JA, Sleeter TD, Carlson CA, Proctor LM (1989) Dominance of bacterial biomass in the Sargasso Sea and it.s erological implications. Mar Ecol Prog Ser 57:207-217

Grebmeier JM, Smith WO Jr, Conover RJ (1995) Biological processes on Arctic continental shelves: ice-ocean-biotic interactions. In: Smith WO Jr, Grebmeier JM (eds) Arctic oceanography: marginal ice zones and continental shelves. American Geophysical Union, Washington, DC, p 231-262

Hanson RB, Shafer D, Ryan T, Pope DH, Lowery HK (1.983) Bacterioplankton in Antarctic Ocean waters during late austral winter: abundance, frequency of dividing cells and estimates of production. Appl Environ Microbiol 45 $1622-1632$

Harrison WG, Cota F (1991) Primary production in polar waters: relation to nutrient availability. Polar Res 10 $87-104$

Hobbie JE, Daley RJ, Jasper S (1977) Use of Nuclepore filters for counting bacteria by epifluorescence microscopy. Appl Environ Microbiol 33:1225-1228

Hodson R, Azam F, Carlucci A, Fuhrman J, Karl D, HolmHansen $O$ (1981) Microbial uptake of dissolved organic matter in McMurdo Sound, Antarctica. Mar Biol 61:89-94

Kirchman D, Soto Y, Van Wambeck F, Bianchi M (1989) Bacterial production in the Rhone River plume: effect of mixing on relationships among microbial assemblages. Mar Ecol Prog Ser 53:267-275

Kirchman DL, Suzuki Y, Garside C, Ducklow HW (1991) High turnover rates of dissolved organic carbon during a spring phytoplankton bloom. Nature 352:612-614

Kirst GO, Wiencke C (1995) Ecophysiology of polar algae. J Phycol 31:181-199

Kristiansen S, Farbrot T, Wheeler PA (1994) Nitrogen cycling in the Barents Sea - seasonal dynamics of new and regenerated production in the marginal ice zone. Limnol Oceanogr 39:1630-1642

Kristiansen S, Lund BAA (1989) Nitrogen cycling in the Barents Sea. I. Uptake of nitrogen in the water column. Deep Sea Res 36:255-268

Lancelot C (1983) Factors affecting phytoplankton extracellu-

Responsible Subject Editor: J. Dolan, Villefranche-sur-Mer, France lar release in the Southern Bight of the North Sea. Mar Ecol Prog Ser 12:115-121

Larsson U, Hagstrom $\AA$ (1982) Fractionated phytoplankton primary production, cxudatc release and bacterial production in a Baltic eutrophication gradient. Mar Biol 67 $57-70$

Lee S. Fuhrman JA (1987) Relationships between biovolume and biomass of naturally derived marine bacterioplankton. Appl Environ Microbiol 53:1298-1303

Lignell R (1990) Excretion of organic carbon by phytoplankton: its relation to algal biomass, primary productivity and bacterial secondary productivity in the Baltic Sea. Mar Ecol Prog Ser 68:85-99

Lignell R (1992) Problems in filtration fractionation of ${ }^{14} \mathrm{C}$ primary productivity samples. Limnol Oceanogr 37:172-178

Loeng $H$ (1991) Features of the oceanographic conditions of the Barents Sea. Polar Res 10:5-18

Obernosterer I, Herndl GJ (1995) Phytoplankton extracellular release and bacterial growth: dependence on the inorganic N:P ratio. Mar Ecol Prog Ser 116:247-257

Parsons T, Maita Y, Lalli C (1984) A manual of chemical and biological methods for seawater analysis. Pergamon Press, Oxford

Peterson GH, Curtis MA (1980) Differences in energy flow through major components of subarctic, temperate and tropical marine shelf ecosystems. Dana 1:53-64

Pomeroy LR (1974) The ocean's food web, a changing paradigm. BioSci 24:499-504

Pomeroy LR, Deibel D (1986) Temperature regulation of bacterial activity during the spring bloom in Newfoundland coastal waters. Science 233:359-361

Pomeroy LR, Macko SA, Ostrom PH, Dunphy J (1990) The microbial food web in Arctic seawater: concentration of dissolved free amino acids and bacterial abundance and activity in the Arctic Ocean and in Resolute Passage. Mar Ecol Prog Ser 61:31-40

Pomeroy LR, Wiebe WJ, Deibel D, Thompson RJ, Rowe GT, Pakulski JD (1991) Bacterial responses to temperature and substrate concentration during the Newfoundland spring bloom. Mar Ecol Prog Ser 75:143-159

Sakshaug E, Bjørge A, Gulliksen B, Loeng H, Mehlum F (1994) Structure, biomass distribution, and energetics of the pelagic ecosystem in the Barents Sea: a synopsis. Polar Biol 14:405-411

Sakshaug E, Slagstad D (1991) Light and productivity of phytoplankton in polar marine systems: a physiological view. Polar Res 10:69-86

Smith WO Jr, Sakshaug E (1990) Polar phytoplankton. In: Smith WO Jr (ed) Polar oceanography. Academic Press, San Diego, p 477-525

Wassmann P, Slagstad D (1993) Seasonal and annual dynamics of particulate carbon flux in the Barents Sea. Polar Biol 13:363-372

Wiebe WJ, Sheldon WM Jr, Pomeroy LR (1992) Bacterial growth in the cold: evidence for an enhanced substrate requirement. Appl Environ Microbiol 58:359-364

Manuscript first received: April 22, 1996

Revised version accepted: September 12, 1996 